\title{
Human Immunodeficiency Virus, Hepatitis B and Hepatitis C Virus Infections Among Injecting and Non-Injecting Drug Users in Inner City Neighborhoods
}

\author{
Lu-Yu Hwang and Carolyn Z. Grimes \\ Center for Infectious Diseases, \\ Division of Epidemiology and Center For Infectious Diseases, \\ School of Public Health, \\ University of Texas Health Science Center at Houston, \\ Houston, Texas, \\ USA
}

\section{Introduction}

Substance abuse is a continuing problem in the United States (US), impacting the individual and their social networks, and impacting society, economically and through public health programs. According to the 2004 National Household Survey on Drug Abuse (NHSDA), there were 19.1 million illicit drug users in the US. Drug use is directly and indirectly related to three blood-borne diseases, HIV, HBV and HCV. Direct exposure occurs through needle sharing and sharing other paraphernalia used to prepare and inject drugs [1-5]. The probability of direct exposure to HIV varies in relation to the procurement, preparation, and injection practices of drug users [6-10]. Frequency of injection and duration of injection are major factors for acquisition of HBV or HCV infections [11-13]. IDU is the primary mode of transmission of HCV in the US [14].

Drug use indirectly contributes to HIV exposure by decreasing inhibitions to engage in high-risk sexual activities and/or increased inhibitory effects on achieving sexual satisfaction $[8,15]$. The use of cocaine has been shown to affect biological and behavioral processes related to HIV infection [16-19]. Engaging in risky sexual behaviors associated with drug use remains a significant risk factor for the acquisition of $\mathrm{HBV}$, also, by men having sex with men (MSM) or heterosexual transmission. This interrelationship between drug use and high-risk sexual behavior makes it crucial to understanding the drug user population in order to develop appropriate interventions [20].

Houston is the fourth largest city and has the eighth highest AIDS caseload in the US. The number of African American and Hispanic Houstonians diagnosed with AIDS are increasing. The reason for the change in focus of the epidemic in Houston, from MSM to persons of color, may be related to the use of crack cocaine [4,5]. Smoking crack cocaine, which became widespread in many poor, African American neighborhoods in the mid1980s, continues to dominate the inner city drug use scene, and crack smokers, in addition to 
injection drug users, are at elevated risk for HIV infection. HBV and HCV were endemic among injecting drug users, even before HIV was introduced into this population. Common risk factors for these blood-borne viral agents, such as multi-person use of injecting equipment and sexual behaviors, have resulted in a high prevalence of infection of all three viruses among drug users. However, a significant proportion does remain at risk, as our previous studies in Houston have shown [4,5] and should be targeted for vaccine prevention.

The purpose of this study was to estimate the prevalence of HIV, HBV and HCV infections and associated socio-demographic, drug use and sexual risk factors in a sample of predominantly African American injecting and non-injecting drug users who were recruited for a HBV vaccination study in Houston, Texas.

\section{Material and methods}

\subsection{Study population}

A sample of 2,779 injecting and non-injecting drug users was recruited for a communitybased HBV vaccine study from February 2004 to October 2007. Participants were recruited from targeted congregation sites such as copping areas, street corners, and crack houses from predominantly two inner city neighborhood communities of Houston, Texas, by using outreach and chain referral recruiting methods. Target neighborhoods were selected based on previous studies $[4,5]$. Potential study participants were asked to go to the designated field site in the area where they were recruited. The eligibility criteria for the study were 1) ages 18 and over, 2) local residence, 3) self-report and confirmed urine drug screen, 4) competent and willing to sign an informed consent form for HIV, HBV, and HCV antibody testing. This study had Institutional Review Board (IRB) approval through the University of Texas Health Science Center Committee for the Protection of Human Subjects.

\subsection{Data collection}

Data collectors received extensive training in obtaining informed consent, keeping participant information confidential, and administering the questionnaire. The interview was conducted confidentially in a private office and was identified only by a unique study identification number. Socio-demographic measures such as age, gender, race/ethnicity, living arrangement, jail history of $>24$ hours; drug use history including lifetime injection drug use (IDU), times injected drugs in past 7 and 30 days, lifetime and number of times shared needles in past 30 days, duration of IDU, types and frequency of drugs used in past 48 hours, 7 and 30 days, and drug treatment history; sexual behaviors such as number of sexual partners in the past 30 days, sexual orientation, condom use, history of sexually transmitted diseases, and trading sex for money or drugs in the past 30 days; history of blood transfusion and occupational exposure to blood. All interviews were verbally administered and recorded electronically via computer administered personal interview (CAPI, QDS, Bethesda, Maryland).

After the interview was completed, drug use was confirmed via urine drug screen, using OnTrak TesTstik, (Varian Inc,. Palo Alto, CA) to test for the presence of cocaine, opiates, and/or methamphetamines. Participants with a positive drug screen were asked to provide $10 \mathrm{ml}$ of peripheral venous blood. Participants received a gratuity of $\$ 10$. 


\subsection{Laboratory methods}

Specimens were screened for HIV 1/2 antibodies, hepatitis B surface antigen (HBsAg), and antibodies to HCV (anti-HCV) by Core Combo HIV-HBsAg-HCV (Core Diagnostics, United Kingdom). Verification of HIV occurred by enzyme immunoassay (EIA), anti-HIV, using Abbott PPC Commander system, third generation HIV antibody test (Abbott Laboratories, Chicago, IL), to HCV (Anti-HCV), hepatitis B surface antigen (anti-HBs) and antibody to hepatitis B core antigen (anti-HBc), by the Abbott AxSYM system, using microparticle enzyme immunoassay (MEIA) (Abbott Laboratories, Chicago, IL).

Case definition for HIV infection was repeatedly reactive specimen by EIA. The detection of HBsAg or anti-HBc, with or without anti-HBs was the definition of HBV infection. HCV infection definition was based on the presence of antibody to $\mathrm{HCV}$. We have 2,779 observations for the HIV analysis, 1,712 for HBV analysis and 1,867 for HCV analysis at the time of manuscript preparation.

\subsection{Statistics}

Data from the questionnaire was imported into SAS 9.1 (Cary, NC) and laboratory results were entered into a Microsoft Access database. Data analysis was performed using STATA 9.0 (College Station, TX) software. Prevalence of HIV, HBV and HCV infections were estimated for the overall population and stratified by injecting status. Univariate and multivariable logistic analyses were performed. Any variable demonstrating a p-value of 0.2 or less or was biologically plausible was carried forward from univariate to multivariable analyses. Variables in the multivariable analyses that had a p-value of 0.05 or less were retained as the final model. Asian and other race were combined with Hispanic race because of small numbers. Variables with more than $10 \%$ missing responses from participants were not considered reliable enough to be examined.

\section{Results}

\subsection{Demographic characteristics of the participants}

Out of the 2,779, $85 \%$ of participants were African American, $11 \%$ White, and $4 \%$ Hispanic or other race with the majority $(76 \%)$ being male. The median age was 43 and ranged from 18 to 76 years. About $3 \%$ reported having received a transfusion and the majority $(78 \%)$ had a history of being in jail $>24$ hours. Twelve percent were currently living in a shelter, and $62 \%$ had a history of being in a drug treatment program.

Almost $98 \%$ of the study participants had smoked crack in the past 7 days, $5 \%$ used methamphetamines and 5\% were heroin users. About one-third (32\%) had a history of injection drug use and $13 \%$ had a history of sharing needles. Almost half $(43 \%)$ reported less than $50 \%$ condom use in the past 30 days. Nearly two-thirds $(68 \%)$ reported a history of STD, with syphilis $(42 \%)$ and gonorrhea $(50 \%)$ being the two most prevalent. About onefifth $(19 \%)$ of the study population included MSM, more than one-third had traded sex for money/drugs in the past 30 days, and $23 \%$ reported having $>3$ male sexual partners and $40 \%$ had $>3$ female sexual partners in past 30 days. 


\subsection{Prevalence and risk factors associated with HIV infection}

The prevalence of HIV infection in this population was $8.7 \%$. Variables that had a significant association with being HIV infected in the univariate analysis were gender, shelter status, sexual orientation, condom use, MSM, trading sex for money or drugs in the past 30 days, and number of sex partners in the past 30 days (Tables 1 and 2). The drug-related variables explored in this analysis did not demonstrate any significant associations. After adjustment, HIV positive participants were more likely to be African American $\{\mathrm{OR}=2.8$ (95\% CI 1.6, $4.9)\}$, Hispanic and other race $\{\mathrm{OR}=2.5(95 \% \mathrm{CI} 1.1,5.7)\}$, men having sex with men $\{\mathrm{OR}=2.5$ $(95 \%$ CI 1.7, 3.5) $\}$, consistent condom users $\{\mathrm{OR}=2.9(95 \%$ CI $2.0,4.2)\}$, and be a male or female that had more than three male partners in the past 30 days $\{\mathrm{OR}=1.6(95 \% \mathrm{CI} 1.0,2.4)\}$ (Table 3). Study participants that lived in a shelter $\{\mathrm{OR}=0.5(95 \% \mathrm{CI} 0.3,0.9)\}$ or a male or female participant that had more than three female partners in the past 30 days $\{\mathrm{OR}=0.4$ (95\% CI 0.2, 0.5)\} were less likely to be HIV positive (Table 3).

\begin{tabular}{|c|c|c|c|c|}
\hline Variables & $\begin{array}{c}\text { Total } \\
\text { Number (\%) }\end{array}$ & $\begin{array}{c}\text { HIV } \\
\text { Positive (\%) }\end{array}$ & $\begin{array}{c}\text { HBV } \\
\text { Positive (\%) }\end{array}$ & $\begin{array}{c}\text { HCV } \\
\text { Positive (\%) }\end{array}$ \\
\hline Total & $2779(100 \%)$ & $8.7 \%$ & $44.8 \%$ & $36.1 \%$ \\
\hline $\begin{array}{l}\text { Gender } \\
\text { Male }\end{array}$ & $2111(76 \%)$ & $7.8 \%$ * & $43.7 \%{ }^{\Delta}$ & $37.5 \% *$ \\
\hline Female & $668(24 \%)$ & $11.7 \%$ & $48.8 \%$ & $30.8 \%$ \\
\hline \multicolumn{5}{|l|}{ Age (years) } \\
\hline$\leq 29$ & $341(12 \%)$ & $7.7 \%$ & $22.5 \% *$ & $10.3 \% *$ \\
\hline 30-39 & $682(25 \%)$ & $10.7 \%$ & $34.4 \%$ & $20.7 \%$ \\
\hline $40-49$ & 1177 (42\%) & $9.1 \%$ & $50.1 \%$ & $44.2 \%$ \\
\hline$>=50$ & $579(21 \%)$ & $6.4 \%$ & $57.5 \%$ & $54.6 \%$ \\
\hline \multicolumn{5}{|l|}{ Race/ethnicity } \\
\hline Caucasian & $302(11 \%)$ & $6.0 \%$ & $37.9 \% *$ & $53.4 \% *$ \\
\hline Blacks & $2354(85 \%)$ & $9.0 \%$ & $46.3 \%$ & $32.9 \%$ \\
\hline Others & $123(4 \%)$ & $10.6 \%$ & $32.9 \%$ & $55.7 \%$ \\
\hline \multicolumn{5}{|c|}{ Currently living in a shelter } \\
\hline No & $2458(88 \%)$ & $9.2 \% *$ & $45.0 \%$ & $35.6 \%$ \\
\hline Yes & $321(12 \%)$ & $4.7 \%$ & $43.3 \%$ & $39.5 \%$ \\
\hline \multicolumn{5}{|l|}{ Ever in drug treatment } \\
\hline No & $1070(38 \%)$ & $9.3 \%$ & $43.3 \%$ & $30.1 \% *$ \\
\hline Yes & $1709(62 \%)$ & $8.3 \%$ & $45.7 \%$ & $39.7 \%$ \\
\hline \multicolumn{5}{|c|}{ Ever received a transfusion } \\
\hline No & $2692(97 \%)$ & $8.7 \%$ & $43.8 \% *$ & $34.1^{*}$ \\
\hline Yes & $87(3 \%)$ & $8.0 \%$ & $53.1 \%$ & 54.0 \\
\hline \multicolumn{5}{|l|}{ Ever in Jail > 24 hours } \\
\hline No & $613(22 \%)$ & $9.5 \%$ & $41.3 \%$ & $27.5 \% *$ \\
\hline Yes & $2166(78 \%)$ & $8.5 \%$ & $45.6 \%$ & $38.3 \%$ \\
\hline
\end{tabular}

${ }^{*} \mathrm{P}$ value $<0.05$

Table 1. Prevalence of HIV, HBV and HCV infections among demographic characteristics in drug users, Houston, Texas. 


\begin{tabular}{|c|c|c|c|c|}
\hline Variables & Total & $\begin{array}{c}\text { HIV } \\
\text { positive } \\
\mathrm{N}(\%)\end{array}$ & $\begin{array}{c}\text { HBV } \\
\text { positive } \\
\mathrm{N}(\%)\end{array}$ & $\begin{array}{c}\mathrm{HCV} \\
\text { positive } \\
\mathbf{N}(\%)\end{array}$ \\
\hline \multicolumn{5}{|l|}{ Drugs use in past 7 days } \\
\hline No & $16(1 \%)$ & $0 \%$ & $46.2 \%$ & $23.1 \%$ \\
\hline Yes & $2763(99 \%)$ & $8.8 \%$ & $45.0 \%$ & $36.2 \%$ \\
\hline \multicolumn{5}{|l|}{ Marijuana } \\
\hline No & $1289(46 \%)$ & $8.5 \%$ & $45.8 \%$ & $38.3 \%$ \\
\hline Yes & $1490(54 \%)$ & $8.9 \%$ & $43.8 \%$ & $34.2 \%$ \\
\hline \multicolumn{5}{|l|}{ Methamphetamines } \\
\hline No & $2632(95 \%)$ & $8.9 \%$ & $45.1 \%$ & $35.5 \% *$ \\
\hline Yes & $147(5 \%)$ & $6.1 \%$ & $39.0 \%$ & $47.2 \%$ \\
\hline \multicolumn{5}{|l|}{ Cocaine } \\
\hline No & $62(2 \%)$ & $11.3 \%$ & $48.0 \%$ & $48.2 \%$ \\
\hline Yes & $2717(98 \%)$ & $8.6 \%$ & $44.7 \%$ & $36.0 \%$ \\
\hline \multicolumn{5}{|l|}{ Heroin } \\
\hline No & $2636(95 \%)$ & $8.8 \%$ & $43.9 \% *$ & $34.8 \%$ * \\
\hline Yes & $143(5 \%)$ & $7.0 \%$ & $59.8 \%$ & $61.6 \%$ \\
\hline \multicolumn{5}{|l|}{ Ever injected drugs } \\
\hline No & $1829(66 \%)$ & $8.6 \%$ & $36.6 \% *$ & $17.9 \%$ * \\
\hline Yes & $950(34 \%)$ & $8.8 \%$ & $59.6 \%$ & $70.0 \%$ \\
\hline \multicolumn{5}{|l|}{ Duration of Injecting } \\
\hline$\leq 5$ years & $2218(80 \%)$ & $8.5 \%$ & $36.0 \% *$ & $26.5 \% *$ \\
\hline$>5$ years & $561(20 \%)$ & $9.4 \%$ & $63.9 \%$ & $78.3 \%$ \\
\hline \multicolumn{5}{|l|}{ Ever shared needle/work } \\
\hline No & $2407(87 \%)$ & $8.7 \%$ & $43.0 \%$ * & $30.2 \%$ * \\
\hline Yes & $369(13 \%)$ & $8.4 \%$ & $55.1 \%$ & $72.1 \%$ \\
\hline \multicolumn{5}{|l|}{ History of STD } \\
\hline No & $875(32 \%)$ & $7.9 \%$ & $37.0 \% *$ & $30.1 \% *$ \\
\hline Yes & $1904(68 \%)$ & $9.1 \%$ & $48.9 \%$ & $39.3 \%$ \\
\hline \multicolumn{5}{|l|}{ History of Syphilis } \\
\hline No & $1597(58 \%)$ & $8.5 \%$ & $41.4 \%$ & $34.5 \%$ * \\
\hline Yes & $1182(42 \%)$ & $9.1 \%$ & $51.1 \%$ & $39.3 \%$ \\
\hline \multicolumn{5}{|l|}{ What $\%$ of use a condom: } \\
\hline Never & $1095(41 \%)$ & $5.7 \%$ * & $40.9 \%$ & $35.5 \%$ \\
\hline Sometimes & $1137(43 \%)$ & $9.2 \%$ & $40.5 \%$ & $36.5 \%$ \\
\hline Always & $445(16 \%)$ & $14.2 \%$ & $40.3 \%$ & $33.1 \%$ \\
\hline \multicolumn{5}{|l|}{ Sexuality } \\
\hline Homosexual & $112(4 \%)$ & $32.1 \% *$ & $50.0 \%$ & $32.0 \% *$ \\
\hline Heterosexual & $2137(77 \%)$ & $7.1 \%$ & $44.7 \%$ & $34.7 \%$ \\
\hline Bisexual & $530(19 \%)$ & $10.2 \%$ & $44.2 \%$ & $42.1 \%$ \\
\hline \multicolumn{5}{|l|}{ Men had sex with men } \\
\hline No & $2248(81 \%)$ & $7.3 \%$ * & $45.4 \%$ & $36.1 \%$ \\
\hline Yes & $531(19 \%)$ & $14.7 \%$ & $44.7 \%$ & $36.2 \%$ \\
\hline
\end{tabular}




\begin{tabular}{l|c|ccc}
\hline \multicolumn{1}{c|}{ Variables } & Total & $\begin{array}{c}\text { HIV } \\
\text { positive } \\
\mathbf{N}(\%)\end{array}$ & $\begin{array}{c}\text { HBV } \\
\text { positive } \\
\mathbf{N}(\%)\end{array}$ & $\begin{array}{c}\text { HCV } \\
\text { positive } \\
\mathbf{N}(\%)\end{array}$ \\
\hline $\begin{array}{l}\text { Traded sex for money/drugs past 30 } \\
\text { days }\end{array}$ & & & \\
No & $1832(66 \%)$ & $7.3 \% *$ & $45.1 \%$ & $36.1 \%$ \\
Yes & $947(34 \%)$ & $11.4 \%$ & $44.0 \%$ & $36.2 \%$ \\
Number of male sex partners in the & & & & \\
past 30 days & $1732(63 \%)$ & $6.0 \% *$ & $43.9 \%$ & $37.3 \%$ \\
0 & $401(14 \%)$ & $10.2 \%$ & $45.9 \%$ & $33.2 \%$ \\
1-2 & $630(23 \%)$ & $15.2 \%$ & $47.4 \%$ & $34.4 \%$ \\
>=3 & & & & \\
Number of female sex partners in & & & & \\
the past 30 days & $919(33 \%)$ & $14.0 \% *$ & $50.0 \% *$ & $37.0 \%$ \\
$\mathbf{0}$ & $759(27 \%)$ & $6.9 \%$ & $41.6 \%$ & $37.7 \%$ \\
$\mathbf{1 - 2}$ & $1091(40 \%)$ & $5.5 \%$ & $43.5 \%$ & $33.9 \%$ \\
\hline >=3 & \multicolumn{3}{|c}{} \\
\hline
\end{tabular}

${ }^{*} \mathrm{P}$ value $<0.05$

Table 2. Prevalence of HIV, HBV and HCV Infections by Drug Use and Sexual Behavior Variables in Past 30 Days among Drug Users in DASH Project.

\begin{tabular}{|c|c|c|c|}
\hline & HIV & HBV & $\mathrm{HCV}$ \\
\hline Risk Factors & OR $(95 \%$ CI) & OR $(95 \% \mathrm{CI})$ & OR (95\% CI) \\
\hline \multicolumn{4}{|l|}{ Race/Ethnicity } \\
\hline White & 1.00 & & \\
\hline African American & $2.8(1.6-4.9) *$ & $1.7(1.2-2.4)^{*}$ & $0.4(0.3-0.6)^{*}$ \\
\hline Other & $2.5(1.1-5.7) *$ & $0.9(0.5-1.6)$ & $1.5(0.8-2.8)^{*}$ \\
\hline Age (per year) & $1.00(0.98-1.02)$ & $1.05(1.04-1.06)^{*}$ & $1.10(1.08-1.12)^{*}$ \\
\hline \multicolumn{4}{|l|}{ Injecting Drug use } \\
\hline Yes & $1.11(0.8-1.5)$ & $2.7(2.27-3.5)^{*}$ & $9.4(7.4-12.1)^{*}$ \\
\hline \multicolumn{4}{|l|}{ Shelter } \\
\hline Yes & $0.5(0.3-0.9)^{*}$ & ----- & ------ \\
\hline \multicolumn{4}{|l|}{$\begin{array}{l}\text { History of blood } \\
\text { transfusions }\end{array}$} \\
\hline Yes & ------ & ----- & $1.6(1.1-2.3)^{*}$ \\
\hline \multicolumn{4}{|l|}{ Condom use } \\
\hline Always & $2.9(2.0-4.2)$ * & ----- & ------ \\
\hline Sometimes & $1.5(1.1-2.2)^{*}$ & & \\
\hline \multicolumn{4}{|l|}{$\begin{array}{l}\text { History of syphilis } \\
\text { diagnosis }\end{array}$} \\
\hline Yes & ------ & $1.30(1.05-1.61)^{*}$ & ------ \\
\hline \multicolumn{4}{|l|}{ Men had sex with men } \\
\hline Yes & $2.5(1.7-3.5)$ * & ------ & ------ \\
\hline $\begin{array}{l}\text { No. of male sex partners } \\
\text { last } 30 \text { days }\end{array}$ & & & \\
\hline
\end{tabular}




\begin{tabular}{l|c|c|c}
\hline & HIV & HBV & HCV \\
\hline \multicolumn{1}{c|}{ Risk Factors } & OR (95\% CI) & OR (95\% CI) & OR (95\% CI) \\
\hline$>3$ & $1.6(1.0-2.4)^{*}$ & ----- & --- \\
$\begin{array}{l}\text { No. of female sex } \\
\text { partners last 30 days }\end{array}$ & & & \\
$>3$ & $0.4(0.2-0.5)^{*}$ & $0.6(0.5-0.8)^{*}$ & ---- \\
$1-2$ & $0.5(0.4-0.8)^{*}$ & & \\
\hline
\end{tabular}

*P value $<0.05$

Table 3. Multivariable Analyses of Risk Factors for HIV, HBV, HCV Infections Among Drug Users, Houston, TX.

To determine if associations differed between females and males and IDUs and non-IDUs, stratification by gender and injecting status were explored. The male study population analysis did not differ from the results from the total study population above (data not shown). Among the 668 female participants, African American race \{OR 3.64 (95\% CI 1.0712.36) $\}$ and always using condoms in the past 30 days $\{\mathrm{OR} 2.18,(95 \% \mathrm{CI}, 1.10-4.33)\}$ were found to be independently associated with HIV infection. Among non-injectors and injectors, the results from the multivariable analyses were fairly consistent with what was found in the total study population (Table 5).

Stratification also occurred by MSM status (Table 5) to determine if MSM status masked IDU as a risk factor for HIV. IDU status was not a significant risk factor for HIV in either the non-MSM or MSM analyses (Table 5).

\subsection{Prevalence and risk factors associated with Hepatitis B virus infection}

The prevalence of HBV in this study was $44.8 \%$. Seropositivity for HBsAg (carrier) was $2.0 \%$ and for anti-HBc (previous or current infection), 38.5\%. Of those with HBV infection, 412 $(53.7 \%)$ out of 766 were co-infected with HCV. In Table 1 and 2, significant differences were observed between HBV positive and negative participants in variables representing gender, age, race, transfusion history, use of heroin in the past 30 days, number of sex partners in the past 30 days, history of STD, history of injection drug use, and history of sharing needles or works. After adjustment in the multivariable analysis, African American race $\{\mathrm{OR}=1.7(95 \%$ CI 1.2, 2.4)\}, increasing age per year $\{\mathrm{OR}=1.05$ (95\% CI 1.04, 1.06)\}, history of injection drug use $\{\mathrm{OR}=2.7(95 \% \mathrm{CI} 2.3,3.5)\}$, and having a history of being diagnosed with syphilis $\{\mathrm{OR}=$ $1.3(95 \%$ CI 1.05, 1.61)\} remained independently associated with HBV infection, while having more than 3 female partners in 30 days, whether male or female, was inversely related to HBV infection $\{\mathrm{OR}=0.6(95 \% \mathrm{CI} 0.5,0.8)\}$ (Table 3$)$.

To determine if non-IDUs shared the same risk characteristics as IDUs for HBV infection, stratification by injection status occurred. After adjusting for confounders in the multivariable analysis, two risk factors for HBV infection remained significant among noninjectors, increasing age and history of STD, while females or males with more than three female partners were less likely to have HBV infection (Table 4). Injectors that had increasing age, of African American race, female and had injected drugs for more than 5 years were all at risk for HBV infection after adjustment (Table 4). 


\begin{tabular}{|c|c|c|c|c|}
\hline & \multicolumn{2}{|c|}{ HBV } & \multicolumn{2}{|c|}{$\mathrm{HCV}$} \\
\hline Risk Factors & $\begin{array}{c}\text { NIDU } \\
\text { OR } \\
(95 \% \mathrm{CI})\end{array}$ & $\begin{array}{c}\text { IDU } \\
\text { OR } \\
(95 \% \mathrm{CI})\end{array}$ & $\begin{array}{c}\text { NIDU } \\
\text { OR } \\
(95 \% \mathrm{CI})\end{array}$ & $\begin{array}{c}\text { IDU } \\
\text { OR } \\
(95 \% \mathrm{CI})\end{array}$ \\
\hline $\begin{array}{l}\text { Gender } \\
\text { Male } \\
\text { Race/Ethnicity } \\
\text { White } \\
\text { African } \\
\text { American }\end{array}$ & 1.1(0.6-2.1) & $\begin{array}{l}1.8(1.1-2.9)^{*} \\
1.7(1.1-2.9)^{*}\end{array}$ & $0.5(0.2-097)^{*}$ & $0.4(0.2-0.7)^{*}$ \\
\hline $\begin{array}{l}\text { Others } \\
\text { Age (per year) }\end{array}$ & $\begin{array}{c}0.4(0.1-1.4) \\
1.03(1.01-1.04)^{*}\end{array}$ & $\begin{array}{c}1.0(0.5-2.2) \\
1.09(1.07-1.12)^{*}\end{array}$ & $\begin{array}{c}1.5(0.5-4.5) \\
1.09(1.07-1.12)^{*}\end{array}$ & $\begin{array}{c}1.3(0.5-3.0) \\
1.10(1.07-1.13)^{*}\end{array}$ \\
\hline $\begin{array}{l}\text { Transfusion } \\
\text { History } \\
\text { Yes } \\
\text { History in jail } \\
>24 \text { hours }\end{array}$ & ----- & ----- & $1.8(1.1-2.93)$ & ----- \\
\hline $\begin{array}{l}\text { Yes } \\
\text { Duration of IDU }\end{array}$ & ----- & ----- & $2.5(1.5-4.1)^{*}$ & ----- \\
\hline $\begin{array}{l}>6 \text { years } \\
\text { Men sex with } \\
\text { men }\end{array}$ & ---- & $2.1(1.4-3.1)^{*}$ & $2.0(1.4-3.0)^{*}$ & ---- \\
\hline $\begin{array}{l}\text { Yes } \\
\text { History of STDs }\end{array}$ & ----- & & ----- & ----- \\
\hline $\begin{array}{l}\text { Yes } \\
\text { Number male } \\
\text { sex partners }\end{array}$ & $1.5(1.1-1.9)^{*}$ & & ---- & ---- \\
\hline $\begin{array}{l}\text { >3 partners } \\
\text { Number female } \\
\text { sex partners } \\
>3 \text { partners }\end{array}$ & $0.6(0.4-0.9)^{*}$ & & ----- & ----- \\
\hline
\end{tabular}

${ }^{*} \mathrm{P}$ value $<0.05$

Table 4. Multivariable Analyses of Risk Factors for HIV Infection Stratified by Injecting Status Among Drug Users, Houston, Texas. 


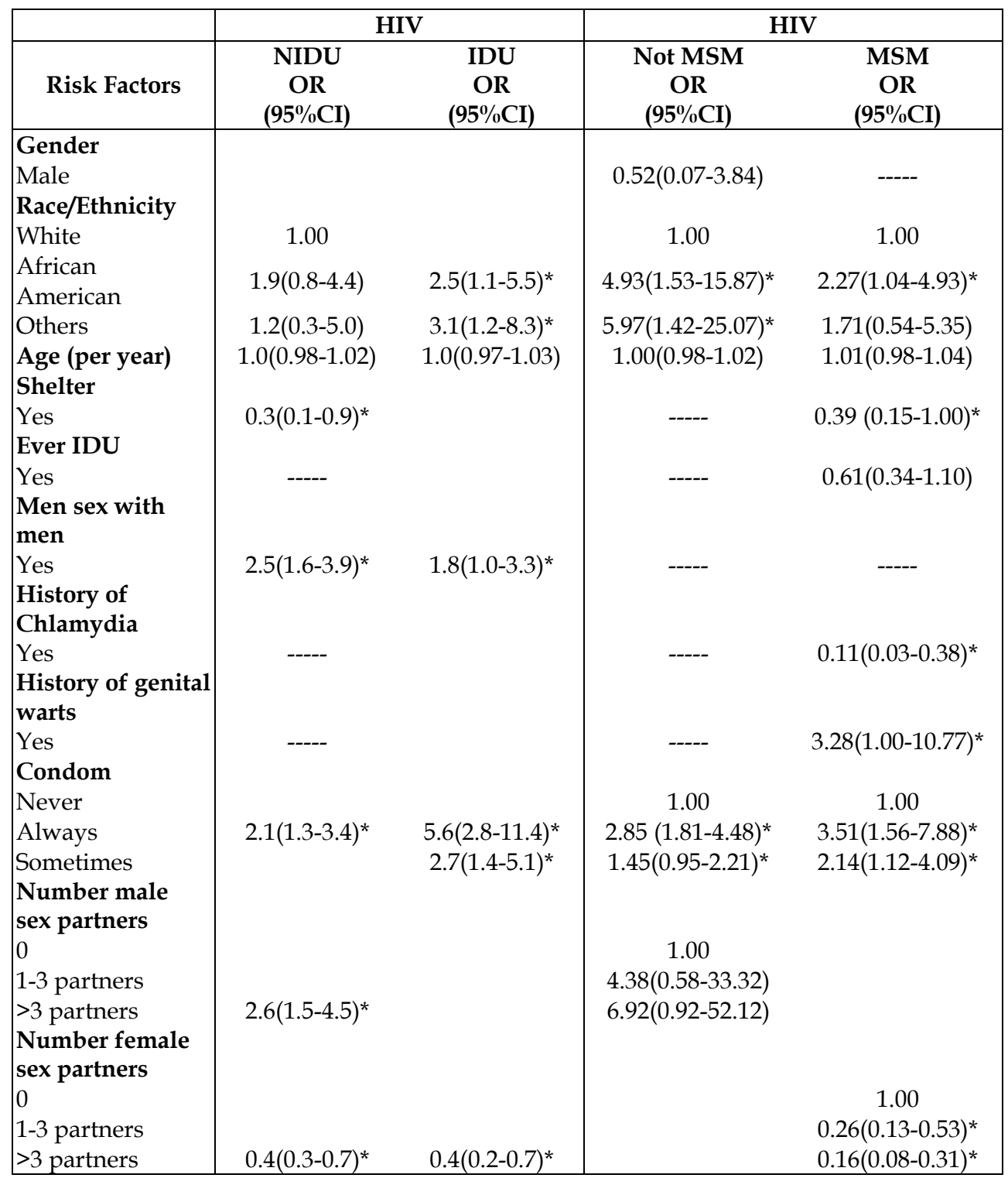

IDU stratification adjusted for history in jail for $>24$ hours, duration of IDU, history of STDs

MSM stratification adjusted for alcohol use, methamphetamine, cocaine use in the past 30 days, crack use in the past 48 hours, duration of IDU, trading for sex/money past 30 days, history of syphilis or genital herpes

${ }^{*}$ p value $<0.05$

Table 5. Multivariable Analyses of Risk Factors for HIV Infection Stratified by Injecting Status and MSM Status Among Drug Users, Houston, Texas. 


\subsection{Prevalence and risk factors associated with Hepatitis C virus infection}

The prevalence of $\mathrm{HCV}$ infection in this population was $36.1 \%$. Of 668 participants infected with HCV, 61.7\% were coinfected with HBV. In Tables 1 and 2, gender, age, race, history of drug treatment, history of transfusion, history of being in jail for $>24$ hours, sexuality, methamphetamine use, heroin use, history of injecting drugs, history of sharing needles or works, sexuality, history of STD, and history of diagnosis or treatment for syphilis all showed significant differences between $\mathrm{HCV}$ positive and negative participants univariately. After adjustment in the multivariable analysis, increasing age $\{O R=1.10(95 \%$ CI 1.08, 1.12) $\}$, history of injection drug use $\{\mathrm{OR}=9.4(95 \% \mathrm{CI} 7.4,12.1)\}$, and having a history of a transfusion $\{\mathrm{OR}=1.6(95 \% \mathrm{CI} 1.1,2.3)\}$ were all still independently associated with HCV infection, while African American race was inversely related to $\mathrm{HCV}$ infection $\{\mathrm{OR}=0.4$ $(95 \%$ CI 0.3, 0.6)\} (Table 3).

Because of the striking difference between injectors (70\%) and non-injectors $(17.9 \%)$ in $\mathrm{HCV}$ positive study participants, and the overwhelming magnitude of association between injection drug use status and $\mathrm{HCV}$ positivity, stratification by injection status was performed to uncover risk characteristics of non-IDUs that may have been masked. In the multivariable analysis, increasing age and having a history of transfusion were found to be independently associated with HCV infection among non-IDUs. African American race was inversely related with HCV infection (Table 4). The significant variables associated with $\mathrm{HCV}$ infection among injectors after adjustment were increasing age, having been in jail for more than 24 hours, and injecting drugs for more than 5 years, while African American race remained inversely associated with HCV infection (Table 4).

\section{Discussion}

This is the first study to evaluate both IDUs and non-IDUs for HIV, HBV and HCV infections in not-in-treatment urban community settings. In this study, prevalence of HIV, $\mathrm{HBV}$, and $\mathrm{HCV}$ was $9 \%, 45 \%$ and $36 \%$ respectively. The predominant risk characteristics associated with HIV infection in drug users are sexual behaviors, especially MSM, while the predominant risk characteristic associated with $\mathrm{HBV}$ and $\mathrm{HCV}$ infections is injection drug use. African American race among IDUs is positively associated with HIV and HBV infections and inversely associated with HCV infection. Increasing age is significantly associated with HBV and HCV infections, but not with HIV infection. Duration of injection drug use is also significantly associated with $\mathrm{HBV}$ and $\mathrm{HCV}$ infections.

Sexual behaviors are the most prevalent risk factors associated with HIV in this study of primarily African American crack cocaine users, which we have found in our previous studies [4, 5]. Any altering substance, such as crack cocaine and methamphetamines, can influence a person to engage in higher frequencies of risky sexual acts, which increases the total number of exposure events, resulting in a higher likelihood of being infected with HIV $[17,21-23]$. Crack cocaine is the drug of choice in this study, as $98 \%$ of the participants used this drug, with very few using other drugs, such as methamphetamines. Several studies have shown that crack cocaine users engage in more unprotected sexual acts, trade sex for money or drugs and have more sexually transmitted diseases, all factors contributing to greater risk for HIV infection [17, 21, 23-26]. One third of the study participants had a history of injection drug use, but no associations were identified between IDU and HIV 
infection in males or females in this study, a conflicting finding from other studies [27-31]. Therefore, crack cocaine use and resulting sexual behaviors from its use infer the most likely way HIV is transmitted amongst drug users in this population.

Study participants that had more than 3 male partners were more likely to have HIV than study participants with less male partners in the past 30 days, emphasizing the point of higher frequencies of sexual acts increases exposure. This result remains significant for nonIDU HIV infected study participants and non-MSM female study participants. Non-IDU and IDU HIV infected MSMs show greater likelihood of infection, adding credence to this finding. Two variables to help explain these risky sexual acts, condom use and trading sex for money or drugs, failed to show a significant association in this study, after adjustment for other variables. Men traded sex for money or drugs more often than women in this study, but neither group showed a significant association. However, $40 \%$ of the men that traded sex had at least one male sexual partner in their lifetime, clouding the association between HIV infection and trading sex due to the collinearity of "trading sex" and "MSM" variables. Frequency of partners may have also been collinear with trading sex, and they really point to the same issue, whether being male or female, heterosexual or homosexual, the more partners and unprotected acts one has, the increase in likelihood for exposure to HIV. Of note, the measurement tool captured sexual activity in the past 30 days, not lifetime risk, and prevalent data does not necessarily reflect the risk profile of the study participant at the time of HIV acquisition. This is the case with condom use. Study participants were more likely to be HIV infected and always use a condom.

The majority of study participants in this study are African American. It is important to note that studies on African American male sexual behaviors show incongruity between reported sexual identity and actual behavior, greater in African American MSM, but other races as well [32]. Williams et al. [33] conducted qualitative analyses of HIV positive gay identifying and non-gay identifying African Americans, and revealed consequences of alienation, low self-esteem, unsupportive networks, a need to protect their HIV status, and inconsistent condom use after acknowledgement of the importance of condom use due to race and sexual orientation status. The higher prevalence of HIV in African American MSM and their higher level of bisexual activity can put African American women at risk, therefore identifying two high risk groups where sensitive interventions need to be developed and delivered in supportive surroundings. Our study also alludes to the importance of African American MSM and their risk for HIV infection. In the MSM stratification analysis, minority races were significantly more at risk for HIV infection versus Caucasians. Most of our MSM were African American, 69\%, followed by Caucasian, 24\%, further heightening the urgency to reach this very high risk group. In this group of drug users, having a male partner, whether bisexual or homosexual, is an overwhelming risk factor for HIV infection, and may be interrelated with injection drug use. IDU does not show to be a significant risk factor in this study for HIV infection, however, the correlation between MSM status and IDU status may be masking the true association. It is logical to assume that an MSM-IDU has the greatest risk for HIV infection.

While sexual practices were associated with HIV infection, injecting practices were significant factors associated with $\mathrm{HBV}$ or $\mathrm{HCV}$ infection in this same population. This 
study supports previous work that risky injection drug use practices result in the transmission of HBV or HCV [4, 7, 11, 13, 34-36], and the longer one injects, in regards to age and duration, in a high risk population, the more likely the person will be infected [11-13, 37, 38]. However, sharing needles was not associated with HBV or HCV in this study, contrasting a previous study by our principal investigator [4], and others [13]. This most likely reflects the strong correlation between history of injection drug use and sharing paraphernalia occurring in this study.

African American IDUs in this study were less likely to have HCV infection, but were more likely to have HBV infection, a conclusion supported by two other studies that did not stratify by injection drug use [4, 39]. One last finding associated with HCV infection among IDUs is history of being in jail for at least 24 hours or more. Possible explanations that were not explored in this study but were found in other studies are sharing needles in jail, and/or receiving a tattoo in jail, but all consistently found a high prevalence of $\mathrm{HCV}$ in the prison/jail systems, heightening the risk for HCV infection [13, 40, 41].

Non-injecting drug users with HBV infection were more likely to have reported a history of STD and be older, but less likely to have more than 3 female sex partners. Non-injectors with HCV infection were associated with transfusion history, increasing age, but less likely to be African American. The median age of the study participants in this study is 43, and documented to be participating in risky drug and sexual behaviors, plus vulnerable to infection, therefore, increasing age is an understandable risk. Sexual behavior in noninjecting drug users may be influenced by stimulant drug activity, especially crack cocaine $[17,21,23-26]$, influencing the drug user to participate in risky sexual behaviors, resulting in increased risk for HIV, hepatitis B, and STDs. From our previous studies and others, there was no significant association found between HCV infection and sexual risk behaviors [4, 34]. Transfusion-associated HCV has been documented [42].

HIV, HBV, and HCV infections, drug use behaviors, and social network dynamics vary widely between populations, even at the neighborhood level. This analysis applies directly only to drug users in the urban neighborhoods in Houston, although generalizations about urban drug users may be used to guide further research in other communities. Every attempt to limit recall bias by limiting the reference period for recall of events and reporting bias through using discretion in interviewing and questions deemed appropriate throughout the pilot study was made, but some bias inevitably exists in the data. High-risk activity may have changed with time, either independent of or dependent on, one's HIV or $\mathrm{HBV} / \mathrm{HCV}$ serostatus, masking true associations that were not covered by the timeframe in question or creating the appearance of spurious associations between $\mathrm{HIV}$ or $\mathrm{HBV} / \mathrm{HCV}$ and current behaviors that had not been expressed at the time of infection.

Characterizing determinants of risk for HIV, HBV, or HCV infection among drug users will improve targeting of health services and prevention education. The greatest association between HIV and drug users in this study was sexual practices, while injecting drug use was the greatest factor associated with HBV and HCV infections. African American drug users are disproportionately affected by these three blood-borne diseases. The vaccine for $\mathrm{HBV}$ is being underutilized in high risk drug users, and outreach efforts to understand the barriers to accepting HBV vaccination need to be explored to prevent further $\mathrm{HBV}$ transmission. Studies targeting young drug users to prevent initiation into injecting or curb 
injecting soon after initiation combined with using social networks for counseling about prevention of these three diseases will impact and interrupt transmission cycles.

\section{Acknowledgements}

We would like to thank the efforts of our field data collection staff, Lawrence Duncan, Madelyn Randle, Janice Robinson, and Edward Johnson, as well as our Field Coordinators, Sandra Timpson, Jay Johnson and Janel Dennison. For supportive data analysis, we would like to thank Shenying Fang and Rui Xia. This study was funded by The National Institute of Drug Abuse (NIDA\# 1R01DA017505).

\section{References}

[1] Shah S.M., Shapshak P., Rivers J. E., Stewart R. V., Weatherby N. L., Xin K. Q. et al. Detection of HIV-1 DNA in needles/syringes, paraphernalia, and washes from shooting galleries in Miami: a preliminary laboratory report. J Acquir Immune Defic Syndr Hum Retrovirol 1996; 11: 301-6.

[2] Bradshaw C. S., Pierce L. I., Tabrizi S. N., Fairley C. K., Garland S. M. Screening injecting drug users for sexually transmitted infections and blood borne viruses using street outreach and self collected sampling. Sex Transm Infect 2005; 81: 53-8.

[3] Mehta S. H., Galai N., Astemborski J., Celentano D. D., Strathdee S. A., Vlahov D. et al. HIV incidence among injection drug users in Baltimore, Maryland (1988-2004). J Acquir Immune Defic Syndr 2006; 43: 368-72.

[4] Hwang L. Y., Ross M. W., Zack C., Bull L., Rickman K., Holleman M. Prevalence of sexually transmitted infections and associated risk factors among populations of drug abusers. Clin Infect Dis 2000; 31: 920-26.

[5] Ross M. W., Hwang L. Y., Leonard L., Teng M., Duncan L. Sexual behaviour, STDs and drug use in a crack house population. Int J STD AIDS 1999; 10: 224-30.

[6] Gold R., Skinner M., Ross M. Unprotected anal intercourse in HIV-infected and non-HIVinfected gay men. J Sex Res 1994; 31: 59-77.

[7] Koester S., Hoffer L. "Indirect Sharing:" Additional HIV risks associated with drug injection. AIDS Public Policy J 1994; 9: 100-05.

[8] McCoy C., Inciardi J. Sex, Drugs, and Continuing Spread of AIDS. Los Angeles: Roxbury Publishing Company, 1995.

[9] Kippax S., Campbell D., Van de Ven P., Crawford J., Prestage G., Knox S. et al. Cultures of sexual adventurism as markers of HIV seroconversion: A case control study in a cohort of Sydney gay men. AIDS Care 1998; 10: 677-88.

[10] Clatts M. C., Heimer R., Abdala N., Goldsamt L. A., Sotheran J. L., Anderson K. T. et al. HIV-1 transmission in injection paraphernalia: heating drug solutions may inactivate HIV-1. J Acquir Immune Defic Syndr 1999; 22: 194-99.

[11] Gyarmathy V. A., Neaigus A., Miller M., Friedman S. R., Des Jarlais D. C. Risk correlates of prevalent HIV, hepatitis B virus, and hepatitis C virus infections among noninjecting heroin users. J Acquir Immune Defic Syndr 2002; 30: 448-56. 
[12] Garten R. J., Lai S., Zhang J., Liu W., Chen J., Vlahov D. et al. Rapid transmission of hepatitis $\mathrm{C}$ virus among young injecting heroin users in Southern China. Int J Epidemiol 2004; 33: 182-88.

[13] Samuel M. C., Doherty P. M., Bulterys M., Jenison S. A. Association between heroin use, needle sharing and tattoos received in prison with hepatitis B and C positivity among street-recruited injecting drug users in New Mexico, USA. Epidemiol Infect 2001; 127: 475-84.

[14] Daniels D., Grytdal S., Wasley A. Surveillance for acute viral hepatitis-United States, 2007. MMWR Surveill Summ 2009; 58: 1-27.

[15] Gordon C.M., Carey M., Carey K.B. Effects of a drinking event on behavioral skills and condom attitudes in men: implications for HIV risk from a controlled experiment. Health Psychol 1997; 16: 490-95.

[16] Booth R.E., Watters J. How effective are risk-reduction interventions targeting injecting drug users? AIDS 1994; 8: 1515-24.

[17] Edlin B. R., Irwin K. L., Faruque S., McCoy C. B., Word C., Serrano Y. et al. Intersecting Epidemics--Crack Cocaine Use and HIV Infection among Inner-City Young Adults. N Engl J Med 1994; 331: 1422-27.

[18] Wilson T., DeHovitz J. A. STDs, HIV, and crack cocaine: a review. AIDS Patient Care STDS 1997; 11: 62-6.

[19] Petry N. M. Alcohol use in HIV patients: What we don't know may hurt us. Int J STD AIDS 1999; 10: 561-70.

[20] Siegal H. A., Falck R. S., Wang J., Carlson R. G. History of sexually transmitted diseases infection, drug-sex behaviors, and the use of condoms among midwestern users of injection drugs and crack cocaine. Sex Transm Dis 1996; 23: 277-82.

[21] Jones D. L., Irwin K. L., Inciardi J., Bowser B., Schilling R., Word C. et al. The High-Risk Sexual Practices of Crack-Smoking Sex Workers Recruited From the Streets of Three American Cities. Sex Transm Dis 1998; 25: 187-93.

[22] Campsmith M. L., Nakashima A. K., Jones J. L. Association between crack cocaine use and high-risk sexual behaviors after HIV diagnosis. J Acquir Immune Defic Syndr 2000; 25: 192-98.

[23] Booth R. E., Watters J. K., Chitwood D. D. HIV Risk-Related Sex Behaviors among Injection Drug Users, Crack Smokers, and Injection Drug Users Who Smoke Crack. Am J Public Health 1993; 83: 1144-48.

[24. McCoy C. B., Lai S., Metsch L. R., Messiah S. E., Zhao W. Injection Drug Use and Crack Cocaine Smoking: Independent and Dual Risk Behaviors for HIV Infection. Ann Epidemiol 2004; 14: 535-42.

[25] Kral A. H., Bluthenthal R. N., Booth R. E., Watters J. K. HIV Seroprevalence among Street-Recruited Injection Drug and Crack Cocaine Users in 16 US Municipalities. Am J Public Health 1998; 88: 108-12.

[26] Hudgins R., McCusker J., Stoddard A. Cocaine use and risky injection and sexual behaviors. Drug Alcohol Depend 1995; 37: 7-14.

[27] Nguyen T. A., Hoang L. T., Pham V. Q., Detels R. Risk factors for HIV-1 seropositivity in drug users under 30 years old in Haiphong, Vietnam. Addiction 2001; 96: 405-13. 
[28] Kozlov A. P., Shaboltas A. V., Toussova O. V., Verevochkin S. V., Masse B. R., Perdue T. et al. HIV incidence and factors associated with HIV acquisition among injection drug users in St Petersburg, Russia. AIDS 2006; 20: 901-6.

[29] Ruan Y., Qin G., Liu S., Qian H., Zhang L., Zhou F. et al. HIV incidence and factors contributed to retention in a 12-month follow-up study of injection drug users in Sichuan Province, China. J Acquir Immune Defic Syndr 2005; 39: 459-63.

[30] Kawichai S., Celentano D. D., Vongchak T., Beyrer C., Suriyanon V., Razak M. H. et al. HIV voluntary counseling and testing and HIV incidence in male injecting drug users in northern Thailand: evidence of an urgent need for HIV prevention. J Acquir Immune Defic Syndr 2006; 41: 186-93.

[31] Barrio G., De La Fuente L., Toro C., Brugal T. M., Soriano V., Gonzalez F. et al. Prevalence of HIV infection among young adult injecting and non-injecting heroin users in Spain in the era of harm reduction programmes: gender differences and other related factors. Epidemiol Infect 2007; 135: 592-603.

[32] Millett G., Malebranche D., Mason B., Spikes P. Focusing "down low": bisexual black men, HIV risk and heterosexual transmission. J Natl Med Assoc 2005; 97(7Suppl): 52S-59S.

[33] Williams J. K., Wyatt G. E., Resell J., Peterson J., Asuan-O'Brien A. Psychosocial issues among gay- and non-gay-identifying HIV-seropositive African American and Latino MSM. Cultur Divers Ethnic Minor Psychol 2004; 10: 268-86.

[34] Hammer G. P., Kellogg T. A., McFarland W. C., Wong E., Louie B., Williams I. et al. Low incidence and prevalence of hepatitis $C$ virus infection among sexually active nonintravenous drug-using adults, San Francisco, 1997-2000. Sex Transm Dis 2003; 30: 919-24.

[35] Bialek S. R., Bower W. A., Mottram K., Purchase D., Nakano T., Nainan O. et al. Risk factors for hepatitis B in an outbreak of hepatitis B and D among injection drug users. J Urban Health 2005; 82: 468-78.

[36] Hagan H., McGough J. P., Thiede H., Weiss N. S., Hopkins S., Alexander E. R. Syringe exchange and risk of infection with hepatitis B and C viruses. Am J Epidemiol 1999; 149: 203-13.

[37] Nyamathi A. M., Dixon E. L., Robbins W., Smith C., Wiley D., Leake B. et al. Risk factors for hepatitis C virus infection among homeless adults. J Gen Intern Med 2002; 17: 134-43.

[38] Garfein R. S., Vlahov D., Galai N., Doherty M. C., Nelson K. E. Viral infections in shortterm injection drug users: the prevalence of the hepatitis $C$, hepatitis $B$, human immunodeficiency, and human T-lymphotropic viruses. Am J Public Health 1996; 86: 655-61.

[39] Butterfield M. I., Bosworth H. B., Stechuchak K. M., Frothingham R., Bastian L. A., Meador K. G. et al. Racial differences in hepatitis B and hepatitis C and associated risk behaviors in veterans with severe mental illness. J Natl Med Assoc 2004; 96: 4352.

[40] Babudieri S., Longo B., Sarmati L., Starnini G., Dori L., Suligoi B. et al. Correlates of HIV, $\mathrm{HBV}$, and $\mathrm{HCV}$ infections in a prison inmate population: results from a multicentre study in Italy. J Med Virol 2005; 76: 311-17. 
[41] Hennessey K. A., Kim A. A., Griffin V., Collins N. T., Weinbaum C. M., Sabin K. Prevalence of infection with hepatitis B and $C$ viruses and co-infection with HIV in three jails: a case for viral hepatitis prevention in jails in the United States. J Urban Health 2009; 86: 93-105.

[42] Armstrong G. L., Wasley A., Simard E. P., McQuillan G. M., Kuhnert W. L., Alter M. J. The prevalence of hepatitis C virus infection in the United States, 1999 through 2002. Ann Intern Med 2006; 144: 705-14. 


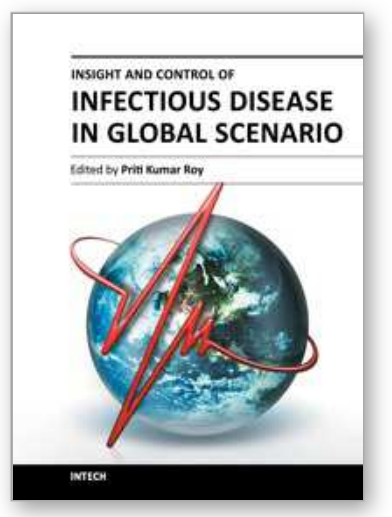

\author{
Insight and Control of Infectious Disease in Global Scenario \\ Edited by Dr. Roy Priti
}

ISBN 978-953-51-0319-6

Hard cover, 442 pages

Publisher InTech

Published online 21, March, 2012

Published in print edition March, 2012

This book is projected as a preliminary manuscript in Infectious Disease. It is undertaken to cover the foremost basic features of the articles. Infectious Disease and analogous phenomenon have been one of the main imperative postwar accomplishments in the world. The book expects to provide its reader, who does not make believe to be a proficient mathematician, an extensive preamble to the field of infectious disease. It may immeasurably assist the Scientists and Research Scholars for continuing their investigate workings on this discipline. Numerous productive and precise illustrated descriptions with a number of analyses have been included. The book offers a smooth and continuing evolution from the principally disease oriented lessons to a logical advance, providing the researchers with a compact groundwork for upcoming studies in this subject.

\title{
How to reference
}

In order to correctly reference this scholarly work, feel free to copy and paste the following:

Lu-Yu Hwang and Carolyn Z. Grimes (2012). Human Immunodeficiency Virus, Hepatitis B and Hepatitis C Virus Infections Among Injecting and Non-Injecting Drug Users in Inner City Neighborhoods, Insight and Control of Infectious Disease in Global Scenario, Dr. Roy Priti (Ed.), ISBN: 978-953-51-0319-6, InTech, Available from: http://www.intechopen.com/books/insight-and-control-of-infectious-disease-in-globalscenario/immunodeficiency-virus-hepatitis-b-and-hepatitis-c-virus-infections-among-injecting-and-non-injectin

\section{INTECH}

open science | open minds

\author{
InTech Europe \\ University Campus STeP Ri \\ Slavka Krautzeka 83/A \\ 51000 Rijeka, Croatia \\ Phone: +385 (51) 770447 \\ Fax: +385 (51) 686166 \\ www.intechopen.com
}

\author{
InTech China \\ Unit 405, Office Block, Hotel Equatorial Shanghai \\ No.65, Yan An Road (West), Shanghai, 200040, China \\ 中国上海市延安西路65号上海国际贵都大饭店办公楼 405 单元 \\ Phone: +86-21-62489820 \\ Fax: +86-21-62489821
}


(C) 2012 The Author(s). Licensee IntechOpen. This is an open access article distributed under the terms of the Creative Commons Attribution 3.0 License, which permits unrestricted use, distribution, and reproduction in any medium, provided the original work is properly cited. 